\title{
キャピラリー電気泳動によるブラジキニンとその代謝物の 同時測定法の開発
}

\author{
福岡栄介 ${ }^{\circledR}$, 鈴木 董, 吉成昌郎*, 奥西秀樹, 宮﨑瑞夫 ${ }^{* *}$
}

(1993 年 8 月 19 日受理)

\begin{abstract}
キャピラリー電気泳動装置によるブラジキニン（BK）とその代謝物（des-Arg ${ }^{9}$-Bradykinin, des-Phe ${ }^{8}$ Arg ${ }^{9}$-Bradykinin, des-Ser ${ }^{6}-$ Pro $^{7}-\mathrm{Phe}^{8}{ }^{8} \mathrm{Arg}^{9}$-Bradykinin）の同時一斉定量法を開発した。この方法により 血しょうに添加した BK 及びその代謝物を $10 \sim 100 \mu \mathrm{g} / \mathrm{ml}$ の範囲で再現性よく分析することができた。 回収率は約 $80 \%$ であった. BK とその代謝物の泳動時間はすべて 10 分以内であった. HPLC 法と比 較して測定感度は多少劣るが, 注入量が $5 \mathrm{nl}$ 程度と少なくてすむこと, 分解能に優れ, 異なる分離条 件を容易に組み合わせることができるなどの利点を有している．本法はこれまで十分に明らかでない BK の生体内運命を解析し, ひいては BK の生理学的, 病態生理学的機能の解明に強力な手段となり得 る.
\end{abstract}

\section{1 緒言}

キャピラリー電気泳動装置 (capillary electrophoresis, 以下 $\mathrm{CE}$ 法とする $)^{1) ~-5) ~}$ は我が国においては 1988 年頃 より利用され始めた。 その分析原理は, 泳動用緩衝液で 満たしたキャピラリーの両端に直流高電圧をかけること により電荷を持った物質が電気泳動されるのに加えて, キャピラリ一内面のシラノール基 (-SiOH) が解離して 電気浸透による緩衝液の流れ（電気浸透流）が発生し物 質を移動する6)ことによる. 従って, 移動度は主として 試料物質の電荷とストークス半径によって決まる778).

CE は従来の電気泳動装置と異なり, (1) 装置が自動化 されている, (2) 分離時間が短い, (3) 分解能が優れてい る, などの特徴を備えており, 高速液体クロマトグラフ イー（HPLC）と比較しても決して劣らない性能を有す るもので, 分析機器としてのその将来性が期待されてい る.

$\mathrm{CE}$ 法はアミノ酸, ペプチド, タンパク質などの分析 に応用すれば, 少量の試料で短時間のうちに感度よく定 量できる測定法であると言われているが，この分野の研 究はまだ緒についたばかりであり, HPLC 法の測定に 関して蓄積された豊富なデータベースに比較すると残念 ながら CE 法のそれははなはだ少ないと言わざるを得

* 大阪医科大学附属病院薬剤部: 569 大阪府高槻市大 学町 2-7

** 大阪医科大学薬理学教室: 同上
ない。

今回著者らは, 生体内に存在し, その生理学的, 病態 生理学的役割が十分解明されていない生理活性ペプチド の一つであるブラジキニン $(\mathrm{BK})^{9110)}$ を取り上げ, BK 及び予測される生体内代謝物を同時に分離・定量する測 定法の開発を試み，ほぼ満足できる測定方法を確立する ことができたので報告する.

\section{2 実験方法}

\section{$2 \cdot 1$ 実験装置}

キャピラリー電気泳動装置: P/ACE SYSTEM 2100 (Beckman)

コンピューター: Personal System/2 Model 55 SX (IBM)

解析ソフトウェア: SYSTEM GOLD (Beckman)

キャピラリー: 溶融シリカキャピラリー $\left(\mathrm{e}-\mathrm{CAP}^{\mathrm{TM}}\right.$, 内径 $75 \mu \mathrm{m} \times$ 全長 $50 \mathrm{~cm}$, Beckman)

使用ガス: 窒素ガス（テイサン）

検出器: UV $214 \mathrm{~nm}$

\section{$2 \cdot 2$ 試 料}

ブラジキニン（BK：Arg-Pro-Pro-Gly-Phe-Ser-ProPhe-Arg): ペプチド研究所, lot No. 410801

Des-Arg ${ }^{9}$-Bradykinin (1-8BK): ペプチド研究所, lot No. 410266

Des-Phe ${ }^{8}-\mathrm{Arg}^{9}$-Bradykinin (1-7BK): BACHEM, lot 
No. 121017

Des-Ser ${ }^{6}-$ Pro $^{7}-$ Phe $^{8}-$ Arg $^{9}$-Bradykinin (1-5BK): BACHEM, lot No. 501389

それぞれを濃度が $1000 \mu \mathrm{g} / \mathrm{ml}$ となるように純水で溶 解し， $-20^{\circ} \mathrm{C}$ で保存した。使用時に純水で $100 \sim 6.25$ $\mu \mathrm{g} / \mathrm{ml}$ の濃度に調製した.

血しょう: ニホンザルの静脈よりヘパリン存在下に採 血し, 3000 回転で 15 分間遠心分離してその上澄を用い た。

\section{$2 \cdot 3$ 回収試験}

ニホンザル血しょう $0.9 \mathrm{ml}$ に氷冷下で， BK，1-5BK， 1-7BK，1-8BK それぞれ $500 \mu \mathrm{g} / \mathrm{ml}$ ，あるいは 1000 $\mu \mathrm{g} / \mathrm{ml}$ を含む水溶液 $0.1 \mathrm{ml}$ を加え, 各々のペプチドの 終濃度を $50 \mu \mathrm{g} / \mathrm{ml}$ 又は $100 \mu \mathrm{g} / \mathrm{ml}$ とした. 次いで，そ の混合溶液 $0.2 \mathrm{ml}$ を限外沪過チューブ（ウルトラフ リ- ${ }^{\circledR}$ C3LGC, 分画分子量 10000 , Millipore）に入れ, $4^{\circ} \mathrm{C}$ にて $2000 \mathrm{~g}$ で 15 分間遠心し, 沪液を試料とし た.

\section{$2 \cdot 4$ 測定条件}

キャピラリー温度: $25^{\circ} \mathrm{C}$

検出波長: $214 \mathrm{~nm}$

前洗浄: $50 \mathrm{mM}$ リン酸緩衝液 ( $\mathrm{pH} \mathrm{3.0),} 10$ 分

注入: 5 秒 (注入量約 $30 \mathrm{nl}$ )

分離: $50 \mathrm{mM}$ リン酸緩衝液 $(\mathrm{pH} 3.0), 23 \mathrm{kV}, 15$ 分

後洗浄 1：500 mM リン酸緩衝液 $(\mathrm{pH} \mathrm{7.0),} 15$ 分 後洗浄 2: 蒸留水, 10 分

\section{結果}

\section{$3 \cdot 1$ アルカリ側での分離条件の検討}

緩衝液の $\mathrm{pH}$ をアルカリ側 $(\mathrm{pH}=8.0 \sim 9.4)$ にした場 合, ピークは 16 分と 19 分に 2 本しか確認できず，各 成分を単独に测定した結果, 前のピークは BK 単独 の, 後のピークは1-8BK, 1-7BK, 1-5BK のピークが重 なったものであることが確認された（Fig. 1)。 又，電 圧を $5.0 \mathrm{kV}$ から $20 \mathrm{kV}$ まで上げたが, 試料注入から ピーク出現までの泳動時間 (migration time, MT) が短 縮される（Table 1）だけであり，各成分ピークの分離 はできなかった。更に，緩衝液の $\mathrm{pH}$ を $8.0,8.5,9.0$ と 変化させた場合でも MT が変化するだけであった。従 って，アルカリ側では $\mathrm{BK}$ と三つの代謝物の分離は不 可能と判断した.

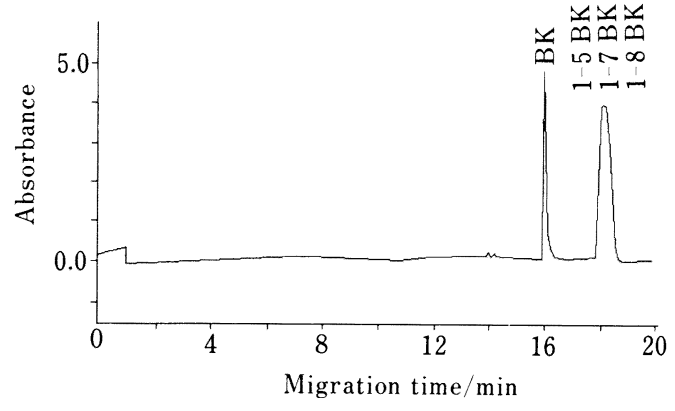

Fig. 1 Electropherogram of a mixture of test peptides, using a buffer solution of $\mathrm{pH} 9.3$ and voltage $8.2 \mathrm{kV}$

BK: Bradykinin; 1-8BK: Des-Arg ${ }^{9}$-Bradykinin; 17BK: Des-Phe ${ }^{8}-\mathrm{Arg}^{9}$-Bradykinin; 1-5BK: Des-Ser ${ }^{6}$ Pro $^{7}-$ Phe $^{8}-$ Arg $^{9}$-Bradykinin

Table 1 Migration time of bradykinin in high $\mathrm{pH}$ boric acid buffer solutions

\begin{tabular}{cccr}
\hline & $\mathrm{pH}$ & $\begin{array}{c}\text { Voltage/ } \\
\mathrm{kV}\end{array}$ & $\begin{array}{c}\mathrm{MT} / \\
\mathrm{min}\end{array}$ \\
\hline $100 \mathrm{mM}$ boric & 8.0 & 20.0 & 3.2 \\
acid buffer & 8.5 & 5.0 & 15.0 \\
& & 8.2 & 9.1 \\
& & 20.0 & 3.6 \\
& 9.0 & 20.0 & 4.1 \\
& 9.4 & 8.2 & 15.5 \\
& & 20.0 & 7.2 \\
\hline
\end{tabular}

\section{$3 \cdot 2$ 酸性側での分離条件の検討}

リン酸緩衝液の濃度と $\mathrm{pH}$ を変化させて $\mathrm{BK}$ とその 代謝物の分離を検討した。酸性側においては BKとそ の代謝物 3 種は基線レベルまで完全に分離された．MT を短くするために条件をかえて検討したが, $\mathrm{pH} 4$ 付近 ではキャピラリーが詰まる現象が生じた。

$50 \mathrm{mM}$ リン酸緩衝液 $(\mathrm{pH} 3.0)$, 電圧 $23.0 \mathrm{kV}$, 電流 $96.1 \mu \mathrm{A}$, 電力 $2210.3 \mathrm{~mW}$ の条件下で, BK の MT は最 短の 12 分を得た。従って,この条件を最適条件とした ( Table 2).

各代謝物のピークの MT は, 1-5BK が 13.5 分, 1$7 \mathrm{BK}$ が 14.5 分，1-8BK が 15.8 分であった (Fig. 2).

しかし，反復測定により MT の延長を認めた。従っ て, BK で得られた MT の 12 分は MT が延長してい る結果である可能性も否定できない.

MT の延長の原因としてぺプチドのキャピラリーへ の吸着による可能性を考え, キャピラリ一の洗浄条件の 
Table 2 Migration time of bradykinin in low $\mathrm{pH}$ phosphate buffer solutions

\begin{tabular}{lccccc}
\hline & $\mathrm{pH}$ & $\begin{array}{c}\text { Voltage/ } \\
\mathrm{kV}\end{array}$ & $\begin{array}{c}\text { Current/ } \\
\mu \mathrm{A}\end{array}$ & $\begin{array}{c}\text { Electric power/ } \\
\mathrm{mW}\end{array}$ & $\begin{array}{c}\mathrm{MT} / \\
\mathrm{min}\end{array}$ \\
\hline \multirow{2}{*}{$100 \mathrm{mM}$ phosphate buffer } & 3.0 & 5.0 & 32.4 & 162.0 & 70.8 \\
& & 6.5 & 43.0 & 279.5 & 54.0 \\
& & 8.0 & 53.0 & 424.0 & 42.4 \\
& & 9.0 & 61.9 & 557.1 & 37.8 \\
& & 12.0 & 83.0 & 996.0 & 23.4 \\
$50 \mathrm{mM}$ phosphate buffer & 2.0 & 15.0 & 111.0 & 1075.7 & 18.8 \\
& & 10.0 & 71.9 & 719.0 & 28.5 \\
$50 \mathrm{mM}$ phosphate buffer & 3.0 & 15.0 & 103.0 & 1545.0 & 15.0 \\
& & 15.0 & 52.2 & 783.0 & 21.6 \\
& & 20.0 & 74.5 & 1490.0 & 17.3 \\
$\mathrm{mM}$ phosphate buffer & 3.0 & 23.0 & 96.1 & 2210.3 & 12.2 \\
& & 23.0 & 39.6 & 910.8 & 16.5 \\
\end{tabular}

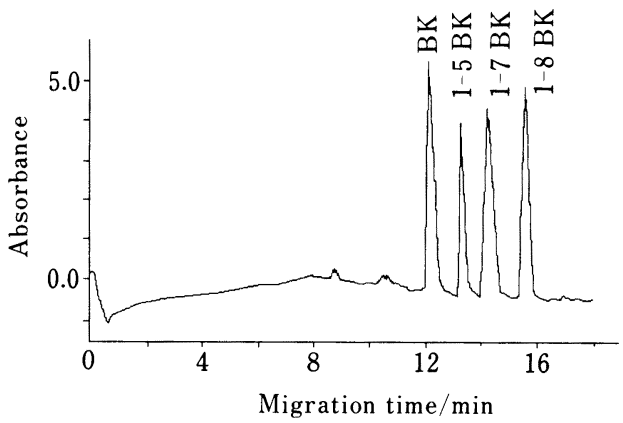

Fig. 2 Electropherogram of a mixture of test peptides, using a buffer solution of $\mathrm{pH} 3.0$

BK: Bradykinin; 1-8BK: Des-Arg ${ }^{9}$-Bradykinin; 1 7BK: Des-Phe ${ }^{8}$-Arg ${ }^{9}$-Bradykinin; 1-5BK: Des-Ser ${ }^{6}$ $\mathrm{Pro}^{7}-\mathrm{Phe}^{8}-\mathrm{Arg}^{9}$-Bradykinin

検討を行った。

\section{$3 \cdot 3$ 洗浄条件の検討}

洗浄液として, $\mathrm{NaOH}$ 液 $(0.1 \sim 1 \mathrm{M}), 100 \mathrm{mM}$ $\mathrm{LiOH}$ 液， $500 \mathrm{mM}$-リン酸緩衝液（pH 7.0）を調製 し，ピーク時間の延長が認められなくなる条件を検討し た。 $\mathrm{NaOH}$ 液は濃度を上げれば洗浄力は上がると考え られたが，上限の濃度は $1 \mathrm{M}$ とした。 $0.1 \mathrm{M} \mathrm{NaOH}$ 液 では 60 分, $1 \mathrm{M} \mathrm{NaOH}$ 液では 20 分間洗浄することに より MT の延長が完全に抑制された．従って，MTの 延長の原因はキャピラリーの洗净の不良にあるといえ る.

従来から，ペプチドなどのキャピラリー洗浄に使用さ
Table 3 Effect of rinse solution and rinse time on migration time

\begin{tabular}{crc}
\hline \multicolumn{1}{c}{ R. sol. } & $\mathrm{RT} / \mathrm{min}$ & $\mathrm{MT}$ \\
\hline $0.1 \mathrm{M} \mathrm{NaOH}$ & $2 \mathrm{~min}$ & + \\
$0.1 \mathrm{M} \mathrm{NaOH}$ & $5 \mathrm{~min}$ & + \\
$0.1 \mathrm{M} \mathrm{NaOH}$ & $20 \mathrm{~min}$ & + \\
$0.5 \mathrm{M} \mathrm{NaOH}$ & $60 \mathrm{~min}$ & - \\
$1.0 \mathrm{M} \mathrm{NaOH}$ & $3 \mathrm{~min}$ & + \\
$1.0 \mathrm{M} \mathrm{NaOH}$ & $15 \mathrm{~min}$ & + \\
$1.0 \mathrm{M} \mathrm{NaOH}$ & $20 \mathrm{~min}$ & - \\
$100 \mathrm{mM} \mathrm{LiOH}$ & $3 \mathrm{~min}$ & + \\
$100 \mathrm{mM} \mathrm{LiOH}$ & $15 \mathrm{~min}$ & + \\
$100 \mathrm{mM} \mathrm{LiOH}$ & $20 \mathrm{~min}$ & - \\
$500 \mathrm{mM}$ phosphate & & \\
buffer (pH 7.0) & $10 \mathrm{~min}$ & + \\
$500 \mathrm{mM}$ phosphate & & - \\
buffer (pH 7.0) & $15 \mathrm{~min}$ & \\
\hline
\end{tabular}

R. sol.: rinse solution; RT: rinse time; $M T$ : migration time; +: prolongation of $\mathrm{MT} ;-$ : no prolongation of MT

れている水酸化リチウム液 ${ }^{11)}$ でも洗浄時間は 20 分を要 した. $500 \mathrm{mM}$-リン酸緩衝液（pH 7.0）では洗净時間が 15 分と最も短縮できたので, 以後はこの緩衝液を採用 することとした (Table 3). 1 回測定ごとにこの洗浄操 作を加えて繰り返し測定したところ，BK の MT は 7.8 分であり，その代謝物の MT はそれぞれ，1-5BK が 8.5 分, 1-7BK が 9.1 分, 1-8BK が 9.9 分であり, 繰り 返し測定で MT の移動は全く認められなかった（Fig. $3)$. 


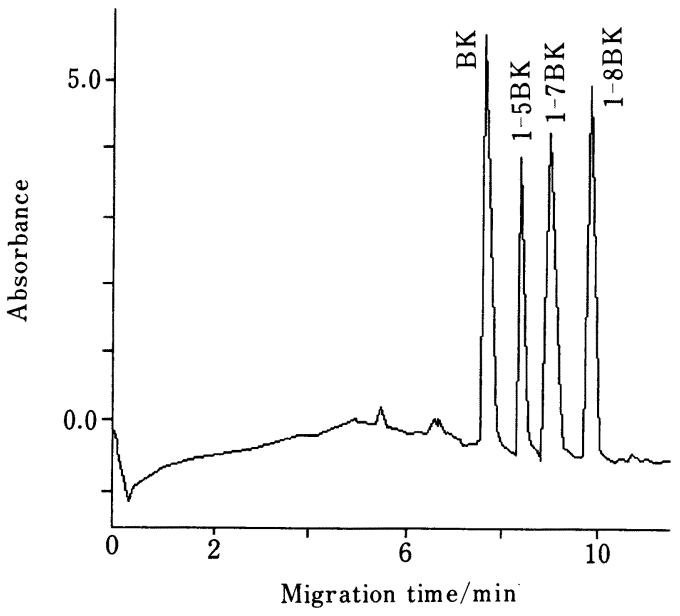

Fig. 3 Electropherogram of a mixture of test peptides at the optimal condition

BK: Bradykinin; 1-8BK: Des-Arg'-Bradykinin; 17BK: Des-Phe ${ }^{8}$ Arg $^{9}$-Bradykinin; 1-5BK: Des-Ser ${ }^{6}$ $\mathrm{Pro}^{7}-\mathrm{Phe}^{8}-\mathrm{Arg}^{9}$-Bradykinin

\section{3•4 再現性について}

$\mathrm{BK}$ と 3 種の代謝物の分離条件が確立されたので, こ の定量法の再現性を検討するために，BK 及びその代謝 物について日内変動試験と日差変動試験を実施した。

$3 \cdot 4 \cdot 1$ 日内変動試験 $\mathrm{BK}, 1-5 \mathrm{BK}, 1-7 \mathrm{BK}, 1-8 \mathrm{BK}$ をそれぞれ異なる 3 濃度で 5 回繰り返し測定し, 日内 再現性を検討した。

$\mathrm{BK}, 1-5 \mathrm{BK}, 1-7 \mathrm{BK}, 1-8 \mathrm{BK}$ の各濃度（低濃度，中濃 度, 高濃度）における測定值の平均値とその RSD 值を Table 4 に示したが，それぞれの RSD 值は，3.3\% 以 下， $5.6 \%$ 以下， $5.6 \%$ 以下， $5.5 \%$ 以下であり，日内再 現性は良好であった。

$3 \cdot 4 \cdot 2$ 日差変動試験 BK, 1-5BK, 1-7BK, 1-8BK をそれぞれ異なる 3 濃度で 3 回繰り返し測定し, 日差 再現性を検討した。

BK，1-5BK，1-7BK，1-8BK の各濃度（25，50，100 $\mu \mathrm{g} / \mathrm{ml})$ における測定值の平均値とその RSD 值を Table 5 に示したが，それぞれの RSD 值は，4.4\% 以 下， $3.3 \%$ 以下， $2.2 \%$ 以下， $2.8 \%$ 以下であり, 日差再 現性は良好であった。

\section{$3 \cdot 5$ 検量線の直線性について}

BK，1-5BK，1-7BK，1-8BK の各成分をそれぞれ 12.5, $25.0,50.0,100.0 \mu \mathrm{g} / \mathrm{ml}$ ずつ含む溶液を調製して検量線 の直線性を検討した。 その結果，各成分につき
Table 4 Interassay coefficients of variance for bradykinin and its metabolites

Concentration of the applied peptide solution

\begin{tabular}{lccc} 
& $25 \mu \mathrm{g} / \mathrm{ml}$ & $50 \mu \mathrm{g} / \mathrm{ml}$ & $100 \mu \mathrm{g} / \mathrm{ml}$ \\
\hline \multirow{3}{*}{$\mathrm{BK}$} & 1.77650 & 3.51446 & 7.18308 \\
& $(3.21 \%)$ & $(3.26 \%)$ & $(1.39 \%)$ \\
$1-5 \mathrm{BK}$ & 1.39127 & 2.88102 & 5.75045 \\
& $(4.85 \%)$ & $(1.66 \%)$ & $(5.59 \%)$ \\
$1-7 \mathrm{BK}$ & 1.50063 & 2.99504 & 5.90294 \\
& $(3.71 \%)$ & $(5.62 \%)$ & $(3.74 \%)$ \\
$1-8 \mathrm{BK}$ & 2.23202 & 4.62737 & 9.01715 \\
& $(5.52 \%)$ & $(3.21 \%)$ & $(3.18 \%)$ \\
\hline
\end{tabular}

The values are the average of corrected peak areas $($ mili-ABS $\times \mathrm{cm})$ from 3 times repeated experiments. The figures in the parentheses represent the RSD value $(\%)$.

Table 5 Interassay coefficients of variance for bradykinin and its metabolites

\begin{tabular}{|c|c|c|c|}
\hline & \multicolumn{3}{|c|}{ Concentration of the applied peptide solution } \\
\hline & $25 \mu \mathrm{g} / \mathrm{ml}$ & $50 \mu \mathrm{g} / \mathrm{ml}$ & $100 \mu \mathrm{g} / \mathrm{ml}$ \\
\hline BK & $\begin{array}{c}1.59531 \\
(4.40 \%)\end{array}$ & $\begin{array}{c}3.44494 \\
(2.40 \%)\end{array}$ & $\begin{array}{c}7.13751 \\
(1.35 \%)\end{array}$ \\
\hline $1-5 B K$ & $\begin{array}{c}1.32907 \\
(1.07 \%)\end{array}$ & $\begin{array}{c}2.77023 \\
(2.81 \%)\end{array}$ & $\begin{array}{c}5.43363 \\
(3.32 \%)\end{array}$ \\
\hline $1-7 \mathrm{BK}$ & $\begin{array}{c}1.46774 \\
(0.83 \%)\end{array}$ & $\begin{array}{c}3.06796 \\
(2.19 \%)\end{array}$ & $\begin{array}{c}5.92189 \\
(1.96 \%)\end{array}$ \\
\hline $1-8 \mathrm{BK}$ & $\begin{array}{l}2.31857 \\
(2.76 \%)\end{array}$ & $\begin{array}{c}4.43762 \\
(1.22 \%)\end{array}$ & $\begin{array}{c}8.72973 \\
(2.40 \%)\end{array}$ \\
\hline
\end{tabular}

The values are the average of corrected peak areas $($ mili-ABS $\times \mathrm{cm})$ from 3 times repeated experiments. The figures in the parentheses represent the RSD value $(\%)$

Table 6 Linearity of standard curve for bradykinin and its metabolites

\begin{tabular}{lll}
\hline BK & $Y=13.76 X+1.18$ & $(r=0.9995)$ \\
$1-5 \mathrm{BK}$ & $Y=18.88 X+0.62$ & $(r=0.9985)$ \\
$1-7 \mathrm{BK}$ & $Y=16.44 X+1.66$ & $(r=0.9988)$ \\
$1-8 \mathrm{BK}$ & $Y=12.31 X+0.06$ & $(r=0.9981)$ \\
\hline
\end{tabular}

$X$ axis: corrected peak area; $Y$ axis: concentration of the peptides

$12.5 \sim 100.0 \mu \mathrm{g} / \mathrm{ml}$ の範囲では極めて高い直線性を示し た.

又，各ペプチドとも $6.25 \mu \mathrm{g} / \mathrm{ml}$ では直線性がなくな るため, $10 \mu \mathrm{g} / \mathrm{ml}$ 付近が測定限界といえる（Table 6). 
Table 7 Recovery rate of bradykinin and its metabolites following the addition of peptide solution ( 50 or $100 \mu \mathrm{g} / \mathrm{ml}$ final concentration) to monkey plasma

\begin{tabular}{|c|c|c|c|}
\hline & & $50 \underset{(n=3)}{\mu \mathrm{g} / \mathrm{ml} \text { sol. }}$ & $100 \underset{(n=3)}{\mu \mathrm{g} / \mathrm{ml} \text { sol }}$ \\
\hline BK & $\begin{array}{c}\text { recovery } \\
\text { (RSD) }\end{array}$ & $\begin{array}{c}77.12 \% \\
(3.98 \%)\end{array}$ & $\begin{array}{c}73.71 \% \\
(2.31 \%)\end{array}$ \\
\hline $1-5 B K$ & $\begin{array}{c}\text { recovery } \\
\text { (RSD) }\end{array}$ & $\begin{array}{l}84.93 \% \\
(2.67 \%)\end{array}$ & $\begin{array}{l}80.99 \% \\
(4.18 \%)\end{array}$ \\
\hline $1-7 \mathrm{BK}$ & $\begin{array}{c}\text { recovery } \\
\text { (RSD) }\end{array}$ & $\begin{array}{l}83.93 \% \\
(2.76 \%)\end{array}$ & $\begin{array}{c}79.23 \% \\
(3.97 \%)\end{array}$ \\
\hline $1-8 \mathrm{BK}$ & $\begin{array}{c}\text { recovery } \\
(\text { RSD })\end{array}$ & $\begin{array}{l}77.37 \% \\
(3.99 \%)\end{array}$ & $\begin{array}{l}83.15 \% \\
(3.81 \%)\end{array}$ \\
\hline
\end{tabular}

$n$ : number of repeat

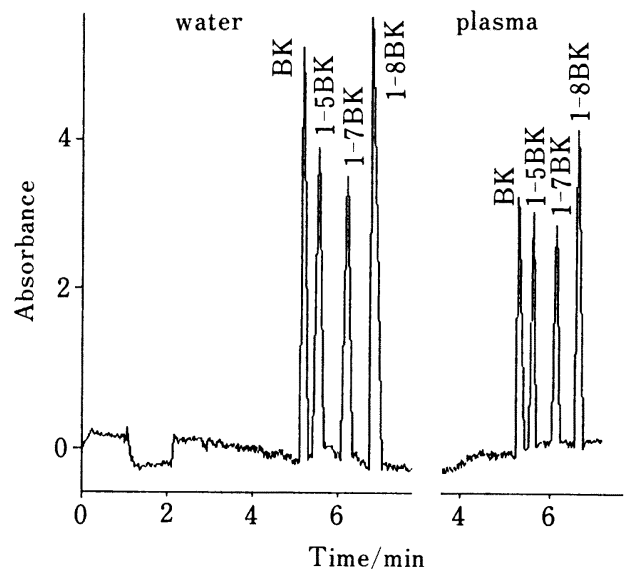

Fig. 4 Electropherogram of a mixture of test peptides in water or plasma

BK: Bradykinin; 1-8BK: Des-Arg ${ }^{9}$-Bradykinin; 17BK: Des-Phe ${ }^{8}$-Arg ${ }^{9}$-Bradykinin; 1-5BK: Des-Ser ${ }^{6}$ Pro $^{7}-$ Phe $^{8}$-Arg ${ }^{9}$-Bradykinin

\section{$3 \cdot 6$ 血しょうからの回収率}

BK とその代謝物をそれぞれサル血しょうに添加し， 2 濃度溶液 $(50 \mu \mathrm{g} / \mathrm{ml}$ と $100 \mu \mathrm{g} / \mathrm{ml})$ について 3 回繰り 返し測定したときの回収率（\%)とRSD 值（\%) を求 めた（Table 7). BK $(50 \mu \mathrm{g} / \mathrm{ml})$ を水溶液及び血しょ う中に添加した場合の比較を Fig. 4 に示した.

$50 \mu \mathrm{g} / \mathrm{ml}$ 溶液では, BK, 1-5BK, 1-7BK, 1-8BK の回 収率はそれぞれ 77.12\%, 84.93\%,83.93\%, 77.37\% であ った. 又 RSD 值は $2.67 \% \sim 3.99 \%$ の範囲にあった。 $100 \mu \mathrm{g} / \mathrm{ml}$ 液については, BK, 1-5BK, 1-7BK, 1-8BK の 回収率はそれぞれ $73.31 \%, 80.99 \%, 79.23 \%, 83.15 \%$ で
あった. 又 RSD 值は $2.31 \%$ 4.18\% の範囲にあった. 全体的には回収率は $80 \%$ 前後の值が得られており, 又 $\mathrm{RSD}$ 值も $5 \%$ 以下であり, 安定した回収率が得られ ていると判断された.

\section{4 考察}

$\mathrm{CE}$ を用いて, BK とその代謝物の再現性の高い微量 一斉分析法を確立した. BK の測定条件は, 前洗浄液及 び分離液に $50 \mathrm{mM}$ リン酸緩衝液 $(\mathrm{pH}=3.0)$ を, 後洗 净液に $500 \mathrm{mM}$ リン酸緩衝液 $(\mathrm{pH}=7.0)$ を用いて, 分 離段階の印加電圧を $23.0 \mathrm{kV}$ と設定した場合に MT が 12 分となり，この設定条件を至適分離条件とした.こ の条件下において測定範囲は $10 \sim 100 \mu \mathrm{g} / \mathrm{ml}$ であり， 血しょう中における BK とその代謝物の回収率は約 $80 \%$ であった.

$\mathrm{CE}$ 法は夕ンパク質, アミノ酸, ペプチド等の多種の サンプルの分離・定量に応用できるとされているが，本 邦においては本法が導入されはじめてまだ 5 年にも満 たない. 従って, 優れた分析機器としての可能性を持っ ていながら現時点においてはなお HPLC 法が主流を保 っているのが実状である.

HPLC 法と比較した場合の GE 法の利点としては, (1) 試料の容量が少なくてよい $(5 \sim 50 \mathrm{nl})$, (2) 分解能が 優れている, (3)プログラミングにより電圧や緩衝液の 切り換えが容易でかつ平衡化に要する時間が短いので至 適条件が見つけやすい, (4)血しょう試料の場合, 前処 理は限外沪過だけでよい,などである.

欠点としては, 測定感度が多少劣る場合があり, $\mu \mathrm{M} \sim \mathrm{mM}$ 程度の濃度が必要と言われている.これは light pass length の短いことによると考えられる. 又, 普及度が低いために，参考データが少ない．今回の BK の分析においても試行錯誤の連続であった。しかし，結 果として多くの有用な情報を導き出すことができ, BK とその代謝物の同時定量に成功した。

これまで BK 及びその代謝物の $\mathrm{CE}$ 分析については 報告がなく，この報告が最初であると思われる．始めに アルカリ $\mathrm{pH}$ 領域で分析条件を模索したが, BK は分離 できたものの，その代謝物（1-5BK, 1-7BK, 1-8BK）は 相互に重なり合って，それぞれの成分に分離できなか た. その理由は, 用いたアルカリ領域（pH 8.0〜9.4） ではキャピラリー内面のシラノール基が強く解離して $\left(-\mathrm{SiO}^{-}\right)^{6) 12)}$ 過大な電気浸透流が生じ分解能が低下する からであろう.この $\mathrm{pH}$ 領域においても $\mathrm{BK}$ の $\mathrm{N}$ 及び $\mathrm{C}$ 両末端の $\mathrm{Arg}$ 残基の側鎖グアニジン基 $\left(\mathrm{p} K_{\mathrm{b}}=12.48\right)^{7)}$ は正荷電しており, $\operatorname{Arg}$ を $\mathrm{N}$ 末端にし 
か持たない三つの代謝物よりも速く泳動される.

一方, $\mathrm{pH} 3$ では最適な分離を得ることができた.こ の $\mathrm{pH}$ においてはシラノール基の解離が弱く ${ }^{10)}$, 最適 な電気浸透流が発生すると考えられる. 又, $\mathrm{pH} 3$ にお いて BK の二つの Arg 残基は強く解離し正電荷 $(2+)$ を持ち最も速く泳動される.これに対し，他の三つのペ プチドは $\mathrm{N}$ 末端 $\operatorname{Arg}(+1)$ 以外は非解離性アミノ酸か ら成っているので, 各々のストークス半径に応じて小さ い物質から先に移動したと考えられる。なお， pH4で はキャピラリーの詰まりを認めたが，これは，おそらく BK やその代謝物の等電点が $\mathrm{pH} 4$ 付近にあるためであ ろう。一般に, 等電点から $0.5 \mathrm{pH}$ 単位ほよ゙離れた $\mathrm{pH}$ が良好な分離をもたらすとされており ${ }^{11)}$, 今回選定し た至適分析条件の $\mathrm{pH} 3$ はこのことからも妥当と考えら れる.

反復測定による MT の延長は, 溶質のキャピラリー 内部への吸着によると考えられた. その理由としては, (1)キャピラリー温度の不安定, (2)洗浄時間の不足, (3) 洗浄液が不適当, などを上げることができる. 従って, 吸着を防止するためには上記の条件をすべて満足させる 必要がある. (1)は簡単に解決できる事柄であり，(2)に ついても洗浄時間を延長すること自体は簡単なことであ るが，測定完了までに時間がかかりあまり現実的ではな い. そこで洗浄液 $(\mathrm{NaOH})$ の濃度を上げる方法を試み たが，強アルカリによるキャピラリーの劣化を考える と，上限の濃度は 1 規定であり， $1 \mathrm{~N} \mathrm{NaOH}$ を用いて も吸着を完全に取り除くには 20 分間の洗浄が必要であ った. 又 (3)に関しても，一部でキャピラリー洗浄に使 用されている水酸化リチウム溶液や高濃度の緩衝液で洗 浄する方法 ${ }^{11)}$ も試みたが, 最終的には, 最も短時間で MT の安定する $500 \mathrm{mM}$-リン酸緩衝液（pH 7.0）が適 当であると結論した.

CE 法における分離電圧, 電力については, 一般的に 電圧を上げると MT は短くなる性質がある. 従って, 測定時間の短縮には電圧を上げればよい。しかし, 使用 可能な電圧には限界がある(最大 $30 \mathrm{kV})$. キャピラ リ一内部の電流が一定值 $(100 \mu \mathrm{A})$ を越えると発熱 し，キャピラリ一内部の緩衝液が沸謄してしまう危険性

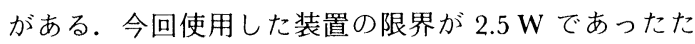
め, 测定電圧を $23 \mathrm{kV}$ とし電力を $2.2 \mathrm{~W}$ 程度とした.

$\mathrm{CE}$ 法による測定値の再現性をみるために, BK とそ の代謝物を同時測定し再現性試験を実施したが，日内変 動, 日差変動ともに RSD 值は $10 \%$ 以下であり，良好 な再現性といえる.

以上のごとく, $\mathrm{CE}$ 法は, $\mathrm{BK}$ とその代謝物の同時定
量が可能となり，生体における BK の代謝過程の検討 に十分応用可能な方法であると言える．又，10〜100 $\mu \mathrm{g} / \mathrm{ml}$ の範囲では，濃度とピークエリアとの間には良好 な直線相関が認められた。

BK を添加したサル血しょうからの BK の回収実験で は $80 \%$ 前後の回収率が得られ，その RSD 值は $5 \%$ 以 下であったことから安定した回収率が得られており，十 分実用に足ると思われる。回収率が $100 \%$ に至らなか った原因としては，限外沪過フィルターへのペプチドの 吸着，あるいは，遠心分離時間（15 分）の不足が考え られる. 今後更に検討を加えてみたい。

$\mathrm{BK}$ の測定法に関しては, 従来 $\mathrm{BK}$ のみの測定にはラ ジオイムノアッセイ ${ }^{13) 14)}$, るいはエンザイムイムノ アッセイ ${ }^{15)}$ な゙が利用されていたが，これらの方法で は代謝物の同時定量はできなかった。従って，BKとそ の代謝物（1-8BK など）を一斉分析する方法として最 近では HPLC 法が主流を占め, 検出器として UV を用 いた方法 ${ }^{16)}$ やポストラベル後に UVで検出する方法 ${ }^{17)}$ などが報告されている.

CE 法は, HPLC 法（通常 $50 \mu \mathrm{l}$ 程度の注入量が用い られている) と比較して $5 \mathrm{nl}$ 程度の少ない注入量で測 定が可能であり，MT は約 10 分程度なので 1 回の測定 時間は非常に短くて済む。一方，連続して試料を測定す る場合は洗浄時間が分離行程の前後に 30〜40 分必要と なり，全行程の所要時間は HPLC 法とほぼ同じにな る.しかし，CE 法は，異なる分析条件を組み合わせる 場合にも HPLC のような平衡化時間をほとんど要せ ず，自動化プログラムの使用で一層の省力化が可能であ る.

ここで確立した手法により，今回の目的であった薬理 学的濃度の $\mathrm{BK}$ 及び関連ペプチドの同時一斉分析は十 分に達成されたが, 試料容量が極微量でよいという特性 を生かせば，前処理力ラムを応用してペプチドを濃縮す ることで生理学的濃度の試料分析にも応用は可能であろ う.

又, レーザー誘導蛍光検出器を用いれば検出感度を約 1000 倍上げることもでき, CE 分析法の生物武料への 更なる応用が期待される.

\section{文献}

1) F. E. P. Mikkers, F. M. Everaerts, T. P. E. M. Verheggen: J. Chromatogr., 169, 11 (1979).

2) B. L. Karger, A. S. Cohen, A. Guttman: J. Chromatogr., 492, 585 (1989).

3) J. W. Jorgenson, K. D. Lukacs: Anal. Chem., 53, 1298 (1981). 
4) H. H. Lauer, D. McManigill: Anal. Chem., 58, 166 (1986).

5) R. M. McCormick: Anal. Chem., 60, 2322 (1988).

6) 白浜啓四郎: 蛋白質核酸酵素, 38, 2235 (1993).

7) 電気泳動学会編: “新版電気泳動実験法”, (1989), (文光堂).

8) S. Terabe, T. Yashima, N. Tanaka, M. Araki: Anal. Chem., 60, 1673 (1988).

9) E. G. Erdös, A. F. Wilde: "Handbook of Experimental Pharmacology", Vol. XXV, Supplement, (1979), (Springer-Verlag, Berlin, Heidelberg, New York).

10) K. D. Bhoola, C. D. Figueroa, K. Worthy: Pharmacol. Rev., 44, 1 (1992).
11) Beckman Instruments 社: 社内資料.

12) 水野昌子, 栃木憲治, 滝守: 分析化学 42, 7 (1993).

13) J. Spragg, K. F. Austen, E. Haber: J. Immunol., 96, 865 (1966).

14) M. L. Mashford, M. L. Roberts: Biochem. Phamacol., 21, 2727 (1972).

15) A. Ueno, S. Oh-ishi, T. Kitagawa, M. Katori: Biochem. Pharmacol., 30, 1659 (1981).

16) F. Marceau, M. Gendreau, J. Barabe, S. STPierre, D. Regoli: Can. J. Physiol. Pharmacol., 59, $131(1981)$.

17) Y. Hiraga, K. Shirono, S. Oh-ishi, S. Sakakibara, T. Kinoshita: Bunseki Kagaku, 33, E279 (1984).

is

Simultaneous analysis of bradykinin and its metabolites by capillary electrophoresis. Eisuke Funuoka, Kaoru Suzuki, Shoro Yoshinari*, Hideki Okunishi and Mizuo Miyazaki ${ }^{* *}$ ( ${ }^{*}$ Department of Pharmacy, Osaka Medical College Hospital; ** Department of Pharmacology, Osaka Medical College, 2-7, Daigaku-cho Takatsukishi, Osaka 569)

We have developed and optimized the capillary electrophoretic procedure for simultaneous analysis of bradykinin (BK) and its metabolites ( $\mathrm{C}$ terminal-truncated peptides). When optimized, the capillary electrophorsis (CE) gave base-line resolution of $\mathrm{BK}$ and des-Arg ${ }^{9}$-BK, des-Phe ${ }^{8}-\mathrm{Arg}^{9}-\mathrm{BK}$, and des-Ser ${ }^{6}-\mathrm{Pro}^{7}-\mathrm{Phe}^{8}-\mathrm{Arg}^{9}-\mathrm{BK}$ within $10 \mathrm{~min}$ upon application. The peak areas were linearly related with the amount of peptides applied, and were highly reproducible $(\mathrm{RSD}<6 \%)$. The peptides were sufficiently recovered $(c a$. $80 \%$ ) from monkey blood plasma which had been immediately ultrafiltrated and applied to the CE. CE is superior to HPLC in that it requires less sample material, yields higher resolution, and it can be readily equilibrated when one buffer is switched to another, although CE is somewhat less sensitive than HPLC inasmuch as an UV detector is used. In addition, we optimized the rinse procedure for the peptides, which was to rinse off the capillary using $500 \mathrm{mM}$ phosphate buffer $\mathrm{pH}$ 7.0. These procedures may enable the determination of the biological fate of $\mathrm{BK}$, and benefit the exploration of the pathophysiological significance of the peptide.

(Received August 19, 1993)

\section{Keyword phrases}

bradykinin; des-Arg ${ }^{9}-\mathrm{BK}$; des- $\mathrm{Phe}^{8}-\mathrm{Arg}^{9}-\mathrm{BK}$; des- $\mathrm{Ser}^{6}-\mathrm{Pro}^{7}-\mathrm{Phe}^{8}-\mathrm{Arg}^{9}-\mathrm{BK}$; capillary electrophoresis. 